\title{
頸動眽ステントの種類による超音波画像の評価
}

\author{
田村 啓和 $^{1)}$, 赤岩 靖久 $^{2)}$, 藤本 剛士 ${ }^{3)}$, 恩田 清 $^{3)}$ \\ 1) 新潟脳外科病院診療放射線部 \\ 2) 獨協医科大学越谷病院神経内科 \\ 3) 新潟脳外科病院脳神経外科
}

\section{Evaluation of ultrasonographic images according to type of carotid artery stent}

\author{
Hirokazu TAMURA $^{1)}$, Yasuhisa AKAIWA ${ }^{2)}$, Takeshi FUJIMOTO ${ }^{3)}$, Kiyoshi ONDA $^{3)}$ \\ 1) Department of Medical Radiology, Niigata Neurosurgical Hospital \\ 2) Department of Neurology, Dokkyo Medical University Koshigaya Hospital \\ 3) Department of Neurosurgery, Niigata Neurosurgical Hospital
}

\begin{abstract}
Purpose: Image evaluation of post-carotid artery stenting (CAS) using non-invasive carotid ultrasonography is widely performed. Three types of carotid artery stents are currently used in Japan: "Carotid WALLSTENT," "PRECISE," and "PROTEGE." Shapes and materials differ for each stent. On post-CAS ultrasonography, findings differ by stent type. We compared ultrasonographic images for each type.

Methods: We weighed B-mode and color Doppler images with each stent type. And, in patients with in-stent plaque, ultrasonographic images were compared with CT angiography. Moreover, a stent was fixed underwater, and long- and short-axis views from a $12-\mathrm{MHz}$ linear probe were examined.

Results: The Carotid WALLSTENT showed fewer artifacts and was best observed in B-mode. In some cases, observation of in-stent plaque was difficult without B-flow or color Doppler imaging. Near-wall artifacts were most frequently observed in PROTEGE. Furthermore, depiction of color flow within PRECISE or PROTEGE was poor, because these stents were curved in accordance with the vessel wall in the proximal portion of the internal carotid artery.

Conclusions: Ultrasonographic images differ according to stent type. Ultrasonography must be performed with an understanding of the features and ultrasonic image characteristics of the stents involved.
\end{abstract}

Keywords: ultrasonography, carotid artery stent, near-wall artifact

(Received February 23, 2016; Accepted May 19, 2016)

目的

内頸動脈狭窄症の血管内治療として, 頸動脈ステント 留置術（carotid artery stenting:CAS）が施行されている. CAS は血管内にステントを留置することにより，狭窄 した血管内腔を広げることができるが，血管内に人工物 が入ることにより，血栓付着を生じステント内再狭窄を 生じることがある。そのため, CAS 後のステント内の 画像評価は重要であり, 非侵襲的で繰り返し行える頸部 エコー検査が多く用いられている.
現在, 本邦で保険収載されている頸動脈ステントは Carotid WALLSTENT ${ }^{\circledR}$ [Boston Scientific], PRECISE ${ }^{\circledR}$ Pro RX [Cordis], PROTEGE ${ }^{\mathrm{TM}} \mathrm{RX}$ [COVIDIEN] の 3 種類であり，それぞれ形状や材質が異なる（Table 1). これらのステントは，狭窄部におけるプラーク性状，血 管の太さや走行など, 臨床的特徴を考慮して選択される.

CAS 後の頸部エコー検査を行った際, ステントの種 類によってステント内の画像描出が異なる。頸動脈ステ ントの種類による画像描出については, magnetic resonance angiography (MRA) や computed tomographic angiography

\section{Reprint request}

田村啓和：=950-1101 新潟県新潟市西区山田 3057 新潟脳外科病院診療放射線部

Hirokazu TAMURA: Department of Medical Radiology, Niigata Neurosurgical Hospital, 3057 Yamada, Nishi-ku, Niigata City, Niigata 950-1101, Japan

E-mail: hrkztmr@yahoo.co.jp, Tel: +81-25-231-5120, Fax: +81-25-231-5130 
Table 1 Structure and material of the carotid stent

\begin{tabular}{lccc}
\hline & Carotid WALLSTENT & PRECISE & PROTEGE \\
\hline & & & \\
& Closed cell & Open cell & Open cell \\
Stent design & Wire mesh & Peak to valley & Peak to peak \\
Structure & Cobalt alloy & Nitinol & Nitinol \\
Material & $0.10 \mathrm{~mm}$ & $0.23 \mathrm{~mm}$ & $0.24 \mathrm{~mm}^{2}$ \\
Stent thickness* & $1.08 \mathrm{~mm}^{2}$ & $5.89 \mathrm{~mm}^{2}$ & $10.71 \mathrm{~mm}^{2}$ \\
Free cell area** & & Carid &
\end{tabular}

${ }^{*}$ Actual measurement value (Carotid WALLSTENT [8 $\times 21$ ], PRECISE [8 $\left.\times 30\right]$, PROTEGE [10 × 40])

${ }^{* *}$ Cited from Bosiers et al. (Eur J Vasc Endovasc Surg 2007; 33: 135-141)

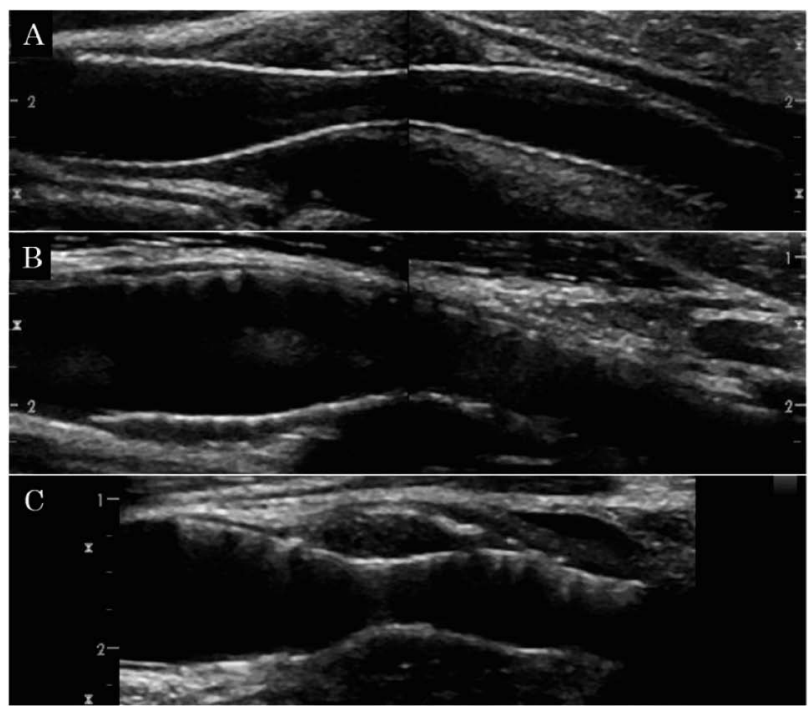

Fig.1 B-mode image of post-CAS

A: Carotid WALLSTENT. B: PRECISE. C: PROTEGE. The Carotid WALLSTENT showed less near wall artifacts in Bmode (A). Near wall artifacts were most frequently observed in PROTEGE (C).

（CTA）による検討が報告されている ${ }^{1-3)}$ 。 しかし，われ われが涉猟したかぎり, 超音波検査における頸動脈ステ ントの画像描出の違いについて検討した報告は見あたら ない，そこで今回，頸動脈ステントの種類による超音波 画像の描出の違いについて比較, 検討を行った.

\section{対象と方法}

当院において 2012 年 4 月から 2015 年 4 月までに CAS を施行し，その後頸部エコー検査を実施した男性 62 例, 女性 8 例の計 70 例 78 血管（症候性 44 血管, 無症候性 34 血管）を対象とした。年齢は 54〜90 歳, 平均 72.9 歳であった。

$\mathrm{B}$ モード画像でステント内プラークを認めた症例につ いて, 同時期に行われた 3D-CTA を観察し, その描出 について比較した。ささらに，各ステントの構造の違いに 着目し, CAS 後における画像描出の特徵について検討

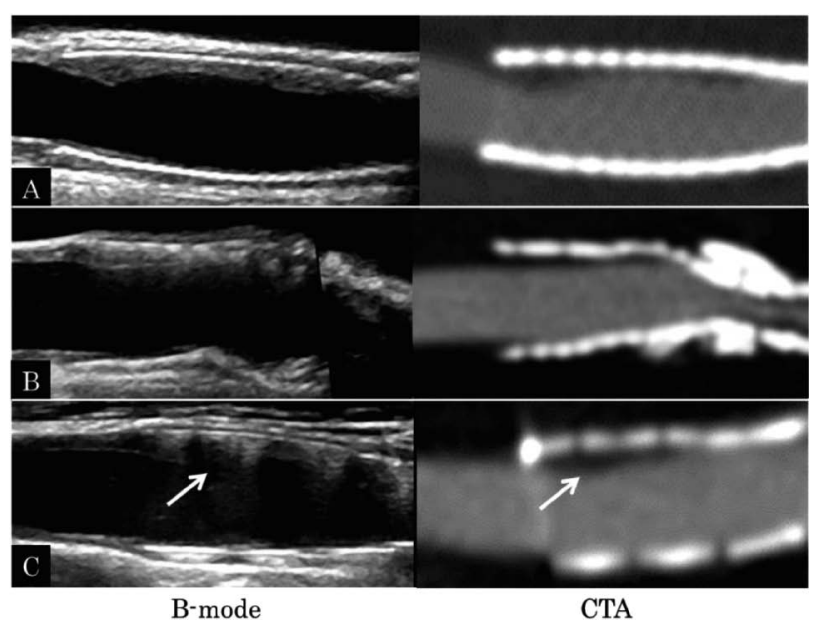

Fig.2 Comparison of B-mode ultrasonography and 3D-CTA in in-stent plaque cases

A: Carotid WALLSTENT. B: PRECISE. C: PROTEGE. Edge of the plaque has not been visualized by the influence of near wall artifacts in the PROTEGE (C).

\section{した。}

生体内と生体外の超音波画像を比較するため, ステン 卜を水中に固定した状態で長軸像と短軸像を描出し，画 像の比較を行った。頸動脈ステント（直径 $\times$ 長さ）は, Carotid WALLSTENT $(8 \mathrm{~mm} \times 21 \mathrm{~mm}), \operatorname{PRECISE}(8 \mathrm{~mm}$ $\times 30 \mathrm{~mm})$, PROTEGE $(10 \mathrm{~mm} \times 40 \mathrm{~mm})$ を使用した。 超音波装置はVivid 7 (GE Healthcare Japan)を使用し, 検査は中心周波数が $9 \mathrm{MHz}$ と $12 \mathrm{MHz}$ のリニアプロー ブを用いて行った．CT装置はAquilion ONE（東芝メ ディカルシステムズ, 栃木）を使用した.

\section{結果}

頸動脈ステントの違いによって, 超音波画像にはそれ ぞれの特徴を認めた（Fig.1）。

まず，それぞれの頸動脈ステントについて，実際の臨 床画像を用いて観察を行い, 同時期に撮影された CTA 画像と比較を行った（Fig.2).

Carotid WALLSTENT では, near wall のアーチファ 


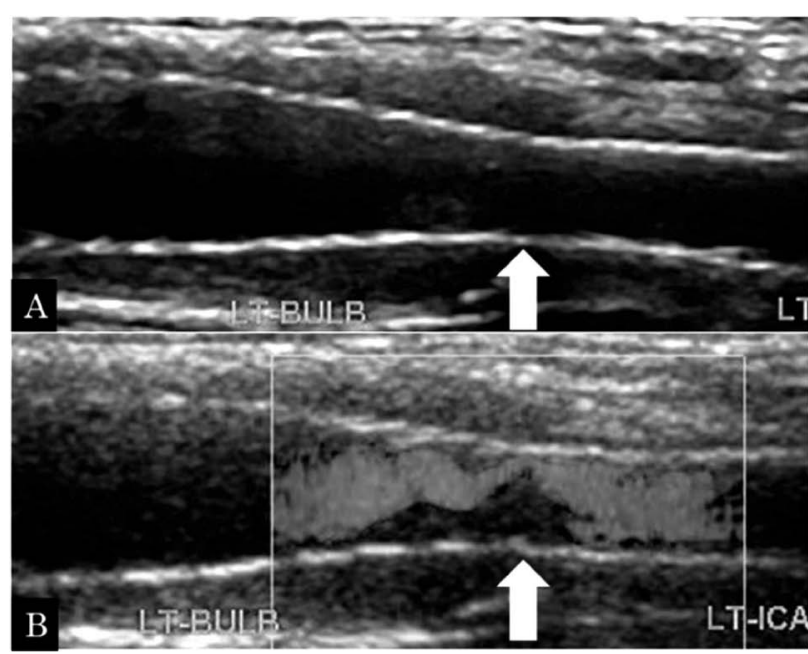

Fig.3 Features of the ultrasound image in the Carotid WALLSTENT

Description of the stent is better in the Carotid WALLSTENT. But in-stent plaque of acute phase may not be evaluated in Bmode (A). It needs to be examined in B-flow (B).

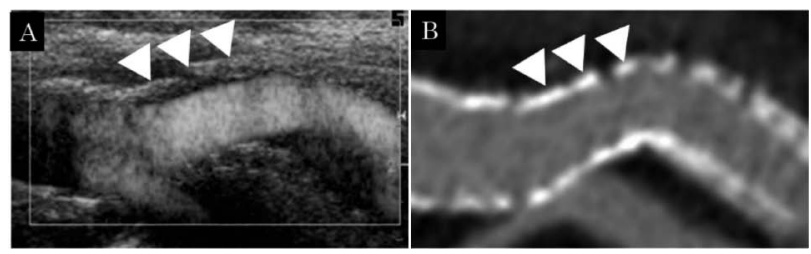

Fig.4 Features of the ultrasound image in the PRECISE

Although the ultrasonography was suspected in-stent plaque (arrowheads) in the proximal portion of the internal carotid artery (A), there was not recognized in-stent plaque in 3D-CTA (B).

クトは目立たず，ステント内腔を良好に描出しえた （Fig.2）が，CAS 後急性期におけるステント内の低輝度 プラークは， $\mathrm{B}$ モード画像のみでは判断が困難な場合が 多く, カラードプラや B-flow などの併用で診断するこ とができた（Fig.3）.

PRECISE では, Carotid WALLSTENTよりも near wall のアーチファクトが強く，ステント内プラークの描 出が不良となる可能性がある (Fig.2)。 また, ステント の湾曲によるカラーの描出不良により，ステント内プ ラークが偽陽性となる症例も存在した（Fig.4）。

PROTEGE は near wall のアーチファクトが強い (Fig.2) が, far wall でも高輝度アーチファクトを伴いプ ラーク辺縁の描出が不良であった (Fig. 5$)$ ）同時期に行っ たCTA と比較し，高輝度アーチファクトがステントス トラットによるものと確認した。

続いて，頸動脈ステントを水中に固定し，Bモード画 像を用いて, 生体外におけるステント単体での描出の違 いについて観察を行った（Fig.6）。水中においては，特 にステントの near wall 側で, アーチファクトの違いが 鮮明であった。 near wall のアーチファクトは Carotid

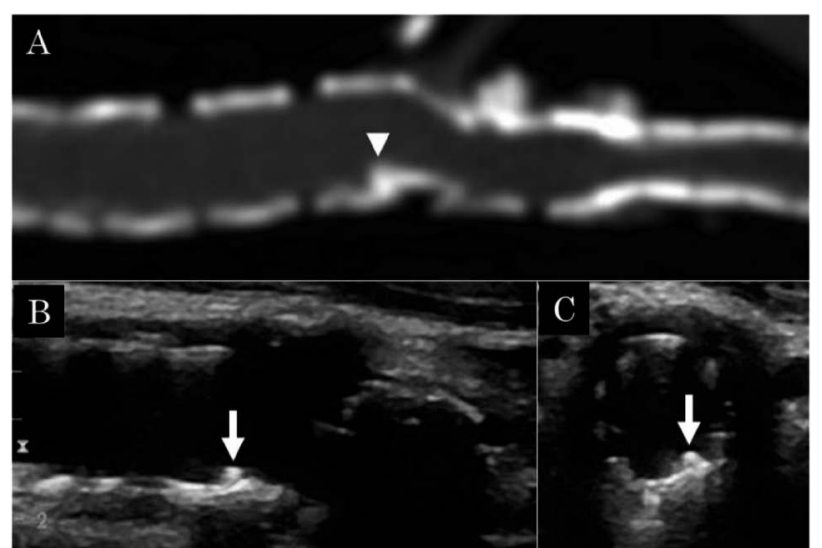

Fig.5 Features of the ultrasound image in the PROTEGE A: 3D-CTA. B: Ultrasonography long axis, C: short axis. Sometimes the stent struts (arrowhead) is rendered as hyperechoic plaque in the ultrasonography (arrows).

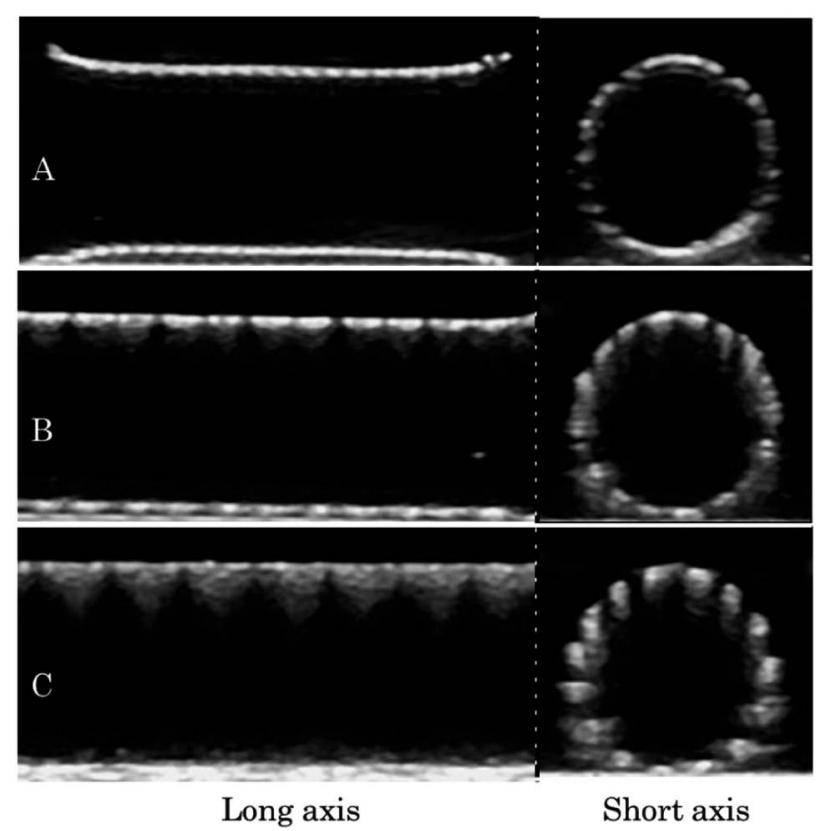

Fig.6 B-mode ultrasonography in the water $(12 \mathrm{MHz}$ linear prove)

A: Carotid WALLSTENT $[8 \times 21]$. B: PRECISE [ $8 \times 30]$. C: PROTEGE $[10 \times 40]$. As well as in vivo, near wall artifacts were most frequently observed in PROTEGE.

WALLSTENT で最も弱く, PROTEGE で最も強く描出 され，生体内における描出とほほ同様のものであった。

考察

今回使用した頸動脈ステントは，それぞれ構造や材質 が異なる（Table 1)，それぞれの生体内での画像の特徴 をまとめると以下のとおりである.

Carotid WALLSTENT は closed cell design のため, 血 管は straightening されやすく, B モードや B-flow の画 像描出を良好に行うことができる。

PRECISE と PROTEGE は open cell design であるた 
め，血管内へ留置した際，ステントは血管壁に沿って展 開される，そのため，湾曲して分岐する内頸動脈起始部 においては，血流の乱流によりカラードプラや B モー ドによる描出が不良となり，さらに near wall のアーチ ファクトも加わり，ステント内プラークの描出が困難に なると考えられる。

PROTEGE は，ストラットのエッジが立ちやすい構 造となっているため，超音波検査では，そのエッジが強 調されて描出され，ステント内プラークとの判別が困難 になる場合がある。

超音波検査は，生体内において超音波の減衰や反射と いった現象が生じる，生体内に伝播された超音波の反射 を受信することで画像化される。CAS 後においては, 超音波はステント間隙を透過して, ステント内の画像を 得ることになる。頸動脈ステントには，大きさや形状は 異なるが free cell area が存在する。 この free cell area の 面積は，ステントの構造上，Carotid WALLSTENT < PRECISE < PROTEGE の順に大きくなる ${ }^{4)}$. この面積 の大きいほうが，超音波も通過しやすいと思われた。し かし，実際には free cell areaの最も小さいCarotid WALLSTENT で, アーチファクトの少ない画像が描出 されていた。このことから，超音波が頸動脈ステントを 通過する際に生じるアーチファクトは, free cell area の 大きさではなく， ステントの材質や他の構造が影響して いるのではないかと考えられる.

生体内において，超音波は反射や減衰，屈折などによ るさまざまなアーチファクトを生じることがある。 ステ ント near wall のアーチファクトについては, 多重反射 によるものと考えられる。多重反射は，超音波が透過す る際, 音響インピーダンスの変化が大きい場合に生じる. 音響インピーダンスは密度 $(\rho)$ と弾性率 $(\mathrm{K})$ の積の 平方根で計算される。頸動脈ステントの材質を考慮した 場合, 配合により数值は多少異なるが，コバルトクロム 合金 $\left(\rho: 8.8 \mathrm{~g} / \mathrm{cm}^{3}, \mathrm{~K}: 240 \mathrm{GPa}\right)^{5)}$ のほうがニチノール $\left(\rho: 6.45 \mathrm{~g} / \mathrm{cm}^{3}, \mathrm{~K}: 29.2 \mathrm{GPa}\right)^{6)}$ より多重反射が大きく なると思われた。しかし，実際には二チノール製ステン トのほうが顕著であった，多重反射は，強い反射体の間 でパルスが折り返すことにより発生する。つまり，使用 する超音波の波長よりも大きい物体で起こると考えられ る。頸部エコー検査は，中心周波数が $7 \mathrm{MHz}$ 以上の高 周波数リニアプローブが推奨されており ${ }^{7)}$, 当院で使用 しているリニアプローブから送信される超音波の波長
は, 生体内の速度を $1,540 \mathrm{~m} / \mathrm{s}$ とした場合, 中心周波数 $9 \mathrm{MHz}$ で $0.171 \mathrm{~mm}, 12 \mathrm{MHz}$ で $0.128 \mathrm{~mm}$ となる.PRECISE やPROTEGE のステントストラットは, これよりも厚 い構造となっており（Table 1)，これらの結果から， near wall のアーチファクトは，ステントの材質よりも 構造が最も影響しているのではないかと考えた。

\section{結語}

頸部エコー検査は，CAS 後のステント内評価におい て有用な検査であるが，ステントの種類によって超音波 画像の描出が異なる. PRECISE や PROTEGE は open cell design で free cell area は大きく，材質的にもステン ト内プラークの描出には優れていると考えたが, Carotid WALLSTENT のほうがそれらに比べて near wall の アーチファクトが少なく, ステント内プラークを描出しやす かった. PRECISE と PROTEGE は, Carotid WALLSTENT に比べてステントが厚く，また，血管内へ留置した際に 血管壁に沿って湾曲して展開されるため，乱流によって ステント内プラークの描出が困難になるものと考えた。 頸部エコー検査を行ううえでは，それらの特徴を把握し て検査を行うことが必要である。

本論文の要旨は，第 34 回日本脳神経超音波学会総会 （2015 年 6 月，京都）において発表した。

\section{文献}

1) Lettau M, Sauer A, Heilad S, et al.: Carotid artery stents: in vitro comparison of different stent designs and sizes using CT angiography and contrast-enhanced MR angiography at $1.5 \mathrm{~T}$ and 3T. AJNR Am J Neuroradiol 2009; 30: 1993-1997.

2) Frölich AM, Pilgram-Pastor SM, Psychogios MN, et al.: Comparing different MR angiography strategies of carotid stents in a vascular flow model: toward stent-specific recommendations in MR follow-up. Neuroradiology 2011; 53: 359-365.

3) Hähnel $S$, Nguyen-Trong TH, Rohde $S$, et al.: 3.0 Tesla contrast-enhanced MR angiography of carotid artery stents: in vitro measurements as compared with 1.5 Tesla. J Neuroraiol 2006; 33: 75-80.

4) Bosiers $\mathrm{M}$, de Donato $\mathrm{G}$, Deloose $\mathrm{K}$, et al.: Does free cell area influence the outcome in carotid artery stenting? Eur J Vasc Endovasc Surg 2007; 33: 135-141.

5) Qizhi C, George T: Biomaterials: A Basic Introduction. Boca Raton: CRC Press, 2014, 155p.

6) Borboni A: Meso- to Micro- Actuators: A Theoretical and Practical Approach. Boca Raton: CRC Press, 2008, 215p.

7）日本脳神経超音波学会・栓子検出と治療学会合同ガイドライ ン作成委員会：頸部血管超音波検査ガイドライン．Neurosonology 2006; 19: 49-69 